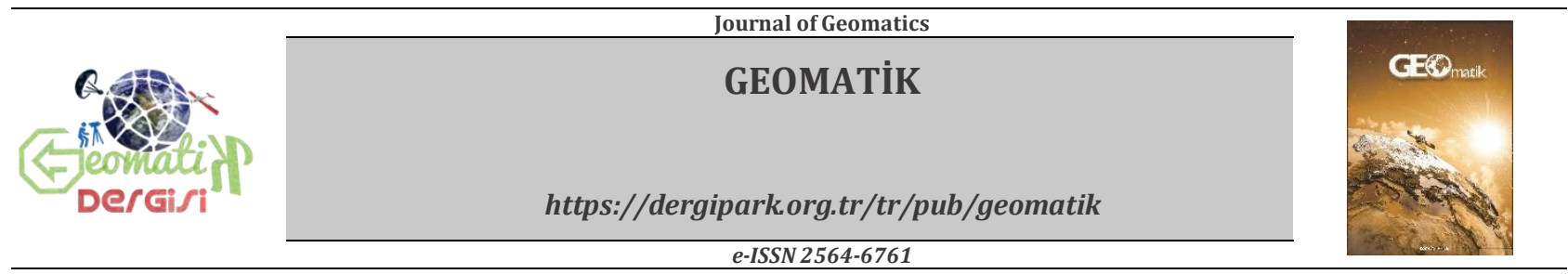

\title{
Elazı̆ğ ve Çevresindeki İllerde Meydana Gelen Tektonik Hareketlerin TUSAGA-Aktif İstasyonlarının Konumlarına Etkisinin Statik Deformasyon Modeller Kullanılarak İncelenmesi
}

\author{
Berkant Konakoğlu*1, Alper Akar² \\ 1 Amasya Üniversitesi, Teknik Bilimler Meslek Yüksek Okulu, Harita ve Kadastro Programı, Amasya, Türkiye \\ ${ }^{2}$ Erzincan Binali Yıldırım Üniversitesi, Meslek Yüksek Okulu, Harita ve Kadastro Programı, Erzincan, Türkiye
}

\author{
Anahtar Kelimeler \\ TUSAGA-Aktif \\ Doğu Anadolu Fay Zonu \\ Deformasyon \\ $\theta^{2}$ Ölçütü \\ İteratif Ağırlıklı Benzerlik \\ Dönüşümü
}

\begin{abstract}
ÖZ
Türkiye Ulusal Sabit GNSS İstasyonları Ağı-Aktif (TUSAGA-Aktif) projesi, KKTC ve Türkiye dâhil olmak üzere toplam 158 adet sabit istasyon ile kullanıclarına hizmet vermektedir. Oluşturulan bu GNSS ağı yardımıyla depremlerin neden olduğu hareketler etkin bir șekilde belirlenebilmektedir. Doğu Anadolu Fay Zonu (DAFZ) üzerinde 04 Nisan 2019 (5.2 Mw), 27 Aralık 2019 (4.8 Mw) ve 24 Ocak 2020 (6.5 Mw) tarihlerinde meydana gelen depremlerin, bu fay zonuna yakın ve çevre illerde bulunan TUSAGA-Aktif istasyonlarını etkilediği düşünülmüştür. Bu kapsamda mevcut TUSAGA-Aktif istasyon noktalarından bölgesel bir GNSS ağı (ADY1, ARPK, BING, DIYB, ELAZ, ERGN, MALY, SIV1 ve TNCE) oluşturulmuş ve ağda bulunan istasyonların hareketleri periyodik olarak incelenmiştir. Yer değiştirme miktarlarını ve yönlerini tespit etmek için jeodezik statik deformasyon modellerinden $\theta^{2}$ Ölçütü ve IWST (İteratif Ağırlıklı Benzerlik Dönüșümü) kullanılmıştır. Yapılan değerlendirme sonucunda her iki yöntemin birbirlerine yakın sonuçlar verdiği belirlenmiștir. En büyük hareket ELAZ istasyonunda 03 Ocak 2019 ile 25 Ocak 2020 periyotları arasında yatay doğrultuda yaklaşı $5.5 \mathrm{~cm}$ (güneybatı), düșey doğrultuda ise yaklaşık $3 \mathrm{~cm}$ (yukarı) olarak belirlenmiștir. Diğer TUSAGA- Aktif istasyonlarında özellikle 24 Ocak 2020 tarihinde 6.5 Mw büyüklüğünde meydana gelen depremden etkilendiği ve yatay doğrultuda yaklaşı 1- $2 \mathrm{~cm}$ ' ye varan hareketlerin olduğu tespit edilmiştir.
\end{abstract}

\section{Investigation of the Effects of Tectonic Movements Occurring in Elazig and Surrounding Provinces on the Positions of TNPGN-Active Stations by Using Static Deformation Models}

\author{
Keywords \\ TNPGN-Active \\ Eastern Anatolian Fault \\ Zone \\ Deformation \\ $\theta^{2}$ Criteria \\ Iterative Weighted \\ Similarity Transformation
}

\begin{abstract}
Turkish National Permanent GNSS Network-Active (TNPGN-Active) Project serves their users with a total of 158 permanent stations, including the Turkish Republic of Northern Cyprus and Turkey. The movements caused by earthquakes can be determined effectively with this GNSS network. It was thought that the earthquakes, occurred on the Eastern Anatolian Fault Zone (DAFZ) on April 04, 2019 (5.2 MW), December 27, 2019 (4.8 MW) and January 24, 2020 (6.5 MW), affected TNPGN-Active stations located in neighbouring provinces close to this fault zone. In this context, a local GNSS network (ADY1, ARPK, BING, DIYB, ELAZ, ERGN, MALY, SIV1 and TNCE) were created from existing TNPGN-Active points and the movements of the stations in the network are periodically examined. $\theta^{2}$ Criteria and IWST (Iterative Weighted Similarity Transformation), which were geodetic static deformation models, were used to determine movement amounts and directions. As a result of the evaluation, it was determined that both methods gave similar results. The largest movement was determined at the ELAZ station between the periods of January 03, 2019 and January 25, 2020 in the horizontal direction about $5.5 \mathrm{~cm}$ (southwest) and in the vertical direction about $3 \mathrm{~cm}$ (up). It was also determined that other TNPGN-Active stations were affected by the earthquake of 6.5 MW in particular on January 24, 2020 and there were movements in these stations up to $1-2 \mathrm{~cm}$ in horizontal direction.
\end{abstract}

*(berkantkonakoglu@amasya.edu.tr) ORCID ID 0000 - 0002 - 8276 - 587X (alperakar@erzincan.edu.tr) ORCID ID 0000 - 0003 - 4284 - 5928
Konakoğlu, B. \& Akar, A. (2021). Elazı̆̆ ve Cevresindeki İllerde Meydana Gelen Tektonik Hareketlerin TUSAGA-Aktif İstasyonlarının Konumlarına Etkisinin Statik Deformasyon Modeller Kullanılarak İncelenmesi. Geomatik, 6(2), 165-178, DOI: $10.29128 /$ geomatik.735565

Gelis Tarihi: 11/05/2020; Kabul Tarihi: 08/06/2020 


\section{GíRiş}

Türkiye, dünyanın en önemli deprem kuşaklarından biri olarak kabul edilen Alp Himalaya dağ oluşum kuşağı üzerinde yer alır (Anadolu ve Kalyoncuoğlu, 2010; Başkan, 2018). Bu nedenle ülkemiz sismik aktivite yönünden dünyadaki en aktif bölgelerden biri olarak kabul edilmektedir (Yıldırım ve diğ., 2014; Aladoğan ve dĭg, 2017). Bu deprem kuşağı, Azor takımadalarından başlayıp, Uzakdoğu'da Endonezya'ya kadar uzanır (Anadolu ve Kalyoncu, 2010).

Depremsel faaliyetlerin aktif olduğu Türkiye, Kuzey Anadolu Fay Zonu (KAFZ), Doğu Anadolu Fay Zonu (DAFZ) ve Batı Anadolu Fay Zonu (BAFZ) olmak üzere 3 ana fay zonuna sahiptir (Kavak, 2020). Bunlardan KAFZ ve DAFZ halen aktif olup Türkiye' deki son yıllarda meydana gelen depremlerin yaşandığı iki ana fay sistemini temsil etmektedir (Çoban ve Sayl, 2018). Türkiye, tektonik yapı bakımından topraklarının \% 98'i deprem riski altında bulunan bir ülke olup, ülkemiz nüfusunun yaklaşık üçte ikisi halen aktif olan bu fay zonları üzerindeki yerleşim alanlarında yaşamaktadır (Ünal, 2019; Başkan, 2018).

DAFZ, Kuzeydoğuda Karlıova'dan bașlayıp güneybatıda Anadolu-Arap-Afrika üçlü ekleminin şekillendiği Kahramanmaraş bölgesinde Ölü Deniz Fayı ile birleşir (Altınoğlu, 2019). Bu kuşak Kuzeydoğu-Güneybatı doğrultusunda uzanmakta olup ortalama $700 \mathrm{~km}$ uzunluğunda ve $30 \mathrm{~km}$ genişliğindedir (Bayramoğlu, 2020).

Ülkemizin bu kadar aktif fay hatları üzerinde olması meydana gelen depremler sonucunda mal ve can kayıplarının da oluşmasına neden olmaktadır. Oluşan depremlerin can kayıpları ile sonuçlanmasının en büyük nedeni mühendislik yapılarında meydana gelen deformasyonlardır. Deformasyon, mühendislik yapılarında ve yer kabuğunda kalıcı/geçici etkilerle oluşan şekil değişikliği olarak adlandırılırken (Gelişkan, 2019), yerkabuğu hareketlerinin saptanması için yapılan jeodezik ölçmelere "deformasyon ölçmeleri", elde edilen ölçülerin değerlendirilerek oluşan deformasyonların istatistiksel yöntemlerle tespit edilmesi ve yorumlanmasına da "deformasyon analizi" adı verilmektedir.

Günümüzde gelişen teknoloji ile birlikte uydu ve uzay teknikleri, derin fayların davranışı hakkında bilgi veren ve deformasyon ölçümlerine imkân sağlayan bir yöntemdir. Bu anlamda GNSS (Global Navigation Satellite System) günümüzde en çok kullanılan deformasyon belirleme ve izleme aracıdır.

GNSS tekniği, 1980'li yıllardan sonra gelişen teknolojiyle birlikte yüksek hassasiyette ölçüm yapmaya olanak sunmuştur (Ervural ve Tuşat,
2019). GNSS tekniğinin diğer tekniklere göre son yıllarda daha çok tercih edilme nedenleri maliyetinin az olması, yüksek hassasiyetli sonuç verebilmesi, ölçü ve hesapta zamandan tasarruf sağlaması olarak sıralanabilir (Kavak, 2020). GNSS tekniği bu özelliklerinden dolayı sadece haritacılık çalışmalarında kullanılmayıp aynı zamanda kabuk hareketlerinin jeodinamiği ile kinematiğini anlamaya yönelik çalışmalarda ve deprem periyotlarındaki deformasyonların belirlenmesi gibi çalışmalarda da oldukça sık kullanılan bir yöntemdir (Yavaşoğlu ve diğ., 2015; Aladoğan ve diğ, 2017).

Deformasyona uğradığı düșünülen yapı veya alanlar jeodezik noktalarla nitelendirilir. $\mathrm{Bu}$ noktaların seçilen koordinat sistemindeki koordinatlarında meydana gelen değişimler incelenerek, deformasyonlar belirlenmeye çalışılır. Deformasyonların belirlenmesinde izlenen işlem adımları, jeodezik deformasyon ağlarının oluşturulması, farklı ölçü periyotlarında yapılan ölçüler, ölçülerin değerlendirilmesi ve sonuçların analiz edilmesi olarak sıralanabilir (Tanrıverdi, 2018).

Ülkemizde GNSS tekniği kullanılarak yapılan çalışmalarda, genellikle fay hattı çevresinde bölgesel ya da jeodezik GNSS ağı kurularak, bu ağ üzerindeki GNSS noktalarının deformasyonları, hızları ve olası sismik kayma oranları tespit edilmektedir (Aktuğ ve diğ., 2016).

2009 yılından beri ülke geneli ve KKTC' de 24 saat kesintisiz ölçüm yapan TUSAGA-Aktif sistemi ve bu sistemin noktalarından oluşan bir GNSS ağ bulunmaktadır (Kutoğlu ve diğ., 2016).

TUSAGA-Aktif sistemi 24 saat kesintisiz tüm istasyonlarında bir saniyelik aralıklarla veri toplar ve bu veriler ana merkezde (Ankara) kaydedilir (Ürüşan, 2014). Sürekli gözlem yapan sabit GNSS istasyonlarından yüksek doğrulukla veri elde edilebilmesi fay hatlarının izlenmesini ve deformasyonların daha etkin bir şekilde belirlenmesini de kolaylaştırmıştır (Ansari ve diğ., 2017). İstasyonların yerleri, tektonik plaka yer değiştirmelerini de gözlemleyebilmek için en iyi verileri sağlayabilecek şekilde seçilmiştir (Yıldırım ve diğ., 2014). TUSAGA-Aktif istasyonlarının dağılımı şekil 1'de gösterilmektedir.

\section{1. Çalışma Alanını Kapsayan Doğu Anadolu Fay Zonunun Yapisı}

Türkiye' nin en büyük ikinci fay zonu olan DAFZ, Avrasya ve Arap levhalarının çarpışmalarının sonucu oluşmuştur (Köküm, 2019). DAFZ, Türkiye' nin Güneydoğusundaki Arap / Anadolu levha sınırını 


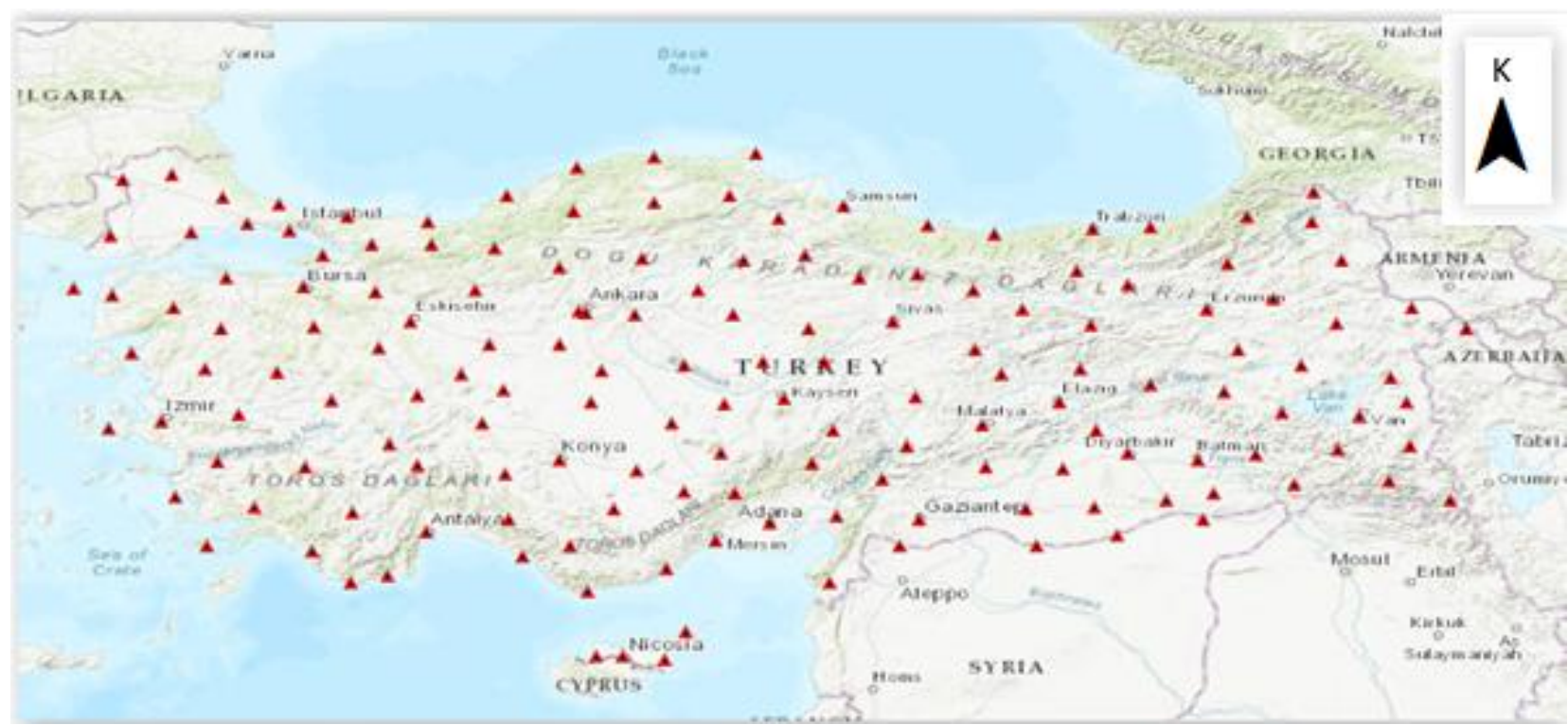

Şekil 1. TUSAGA-Aktif istasyonlarının dağılımı

olușturan, morfolojik olarak ayrı ve sismik olarak aktif bir sol yanal doğrultu atımlı faydır (Çoban ve Sayıl, 2018; Köküm, 2019; Şahin, 2019). DAFZ aynı zamanda eğim atımına da sahip, birbirine paralel kayma düzlemleri boyunca hareket eden, birkaç metre ile 10 kilometreye ulaşan bir fay zonunu temsil eder (Tanrıverdi, 2018). DAFZ, farklı doğrultu eğim ve hareket bileșenlerine sahip olan farklı fay kollarının oluşturduğu birbirlerinden bağımsız geometrilerde zonal bir yapıdan oluşmaktadır (Tan ve Eyidoğan, 2019; Khalifa, 2018; Kayın, 2019).

DAFZ, Bingöl, Palu, Hazar Gölü, Pötürge, Sincik, Narlı, Türkoğlu dolaylarından geçerek İskenderun Körfezine kadar uzanır. Kuzeydoğu-Güneybatı doğrultusunda uzanan bu kuşak ortalama $700 \mathrm{~km}$ uzunluğunda olup, $30 \mathrm{~km}$ genişliktedir.

Çalışma alanının bulunduğu Elazığ ili ve çevresi birbirinden farklı iki ayrı deprem bölgesinden oluşmaktadır. Türkiye deprem bölgeleri haritasına göre Elazı̆̆ kent merkezinin bulunduğu alan ile Kuzey bölümü tümüyle 2 . derece deprem bölgesi içinde yer alırken, Palu İlçesinin de üzerinde yer aldığı Doğu Anadolu Fay Zonu üzerinde kalan, Elazığ güneyindeki bölge ise 1 . derece deprem bölgesi içerisindedir (Bayramoğlu, 2020).

Yaklaşı $500 \mathrm{~km}$ uzunluğu ile Türkiye'nin en büyük ikinci fay sistemi olan, sol yönlü doğrultu atılımlı DAFZ üzerinde 04 Nisan 2019, 27 Aralık 2019 ve 24 Ocak 2020 tarihlerinde depremler meydana gelmiştir. Bu çalışmada, analiz edilen TUSAGA-Aktif istasyonları Adıyaman (ADY1), Arapkir (ARPK), Bingöl (BING), Diyarbakır (DIYB), Elazı̆̆ (ELAZ), Ergani (ERGN), Malatya (MALY), Siverek (SIV1) ve Tunceli (TNCE) olup, seçilen bu istasyonlarda toplanan dört farklı periyottaki $(03$ Ocak 2019, 05 Nisan 2019, 28 Arallk 2019 ve 25 Ocak 2020) GNSS verileri TUSAGA-AKTIF veri internet arayüzünden indirilmiştir. Her bir periyot ayrı ayrı serbest olarak dengelenmiş, $\theta^{2}$ Ölçütü ve IWST modelleri ile deformasyon analizleri yapılmıştır. 03 Ocak 2019 günü Elazı̆̆ ili ve çevresindeki istasyonların yer aldığı bölgede deprem olmadığı göz önüne alınarak bu gün yapılan ölçülerle elde edilen koordinat değerleri referans olarak seçilmiştir. Diğer periyotlar ise deprem gününün ertesi günü olacak şekilde belirlenmiştir. Analiz sonucunda yer değiştirmelerin anlamlı olup olmadığı incelenmiş ve yer değiştirme miktarları tespit edilmiştir. Çalışma periyodu içerisinde (3 Ocak 2019-24 Ocak 2020) çalışma alanını kapsayan bölgede meydana gelen depremler şekil 2'de gösterilmiștir.

\section{2. Çalışma Alanı}

TUSAGA-Aktif istasyonlarında meydana gelen deformasyonları belirleyebilmek için deprem bölgesine yakın ve çevresindeki illerde bulunan ADY1, ARPK, BING, DIYB, ELAZ, ERGN, MALY, SIV1 ve TNCE istasyonlarından oluşan bölgesel bir GNSS ağı oluşturulmuştur. $\mathrm{Bu}$ istasyonların dağılımı şekil 3'deki gibidir. TUSAGA-Aktif internet arayüzünden ücretsiz olarak sunulan 30 sn'lik GNSS verileri indirilmiştir. GNSS verilerinin değerlendirilmesi için Topcon Tools yazılımı kullanılmıştır. Tüm periyotlardaki ölçülerde GPS ve GLONASS gözlemleri birlikte kullanılarak değerlendirme işlemi yapılmıştır. Baz çözümlerinin değerlendirme aşamasında baz mesafelerinin uzun olması nedeniyle IGS (International Geodetic Survey) ürünlerinden hassas efemeris dosyaları kullanılmış, yükseklik açısı $5^{\circ}$ olarak seçilmiştir.

Değerlendirme yapılırken atmosferik etkileri modelleme aşamasında Niell troposferik modeli kullanılmıştır. Verilerdeki faz sıçramaları kontrol edilmiş, kötü olan ölçüler belirlenip iyi durumda olan ölçülere müdahale edilmeden elemine edilmiştir.

Çalışma alanında meydana gelen deprem merkezlerinin çalışma kapsamında seçilen illerde bulunan TUSAGA-Aktif istasyonlarına olan yaklaşı mesafeleri Tablo 1'de gösterilmiștir. 


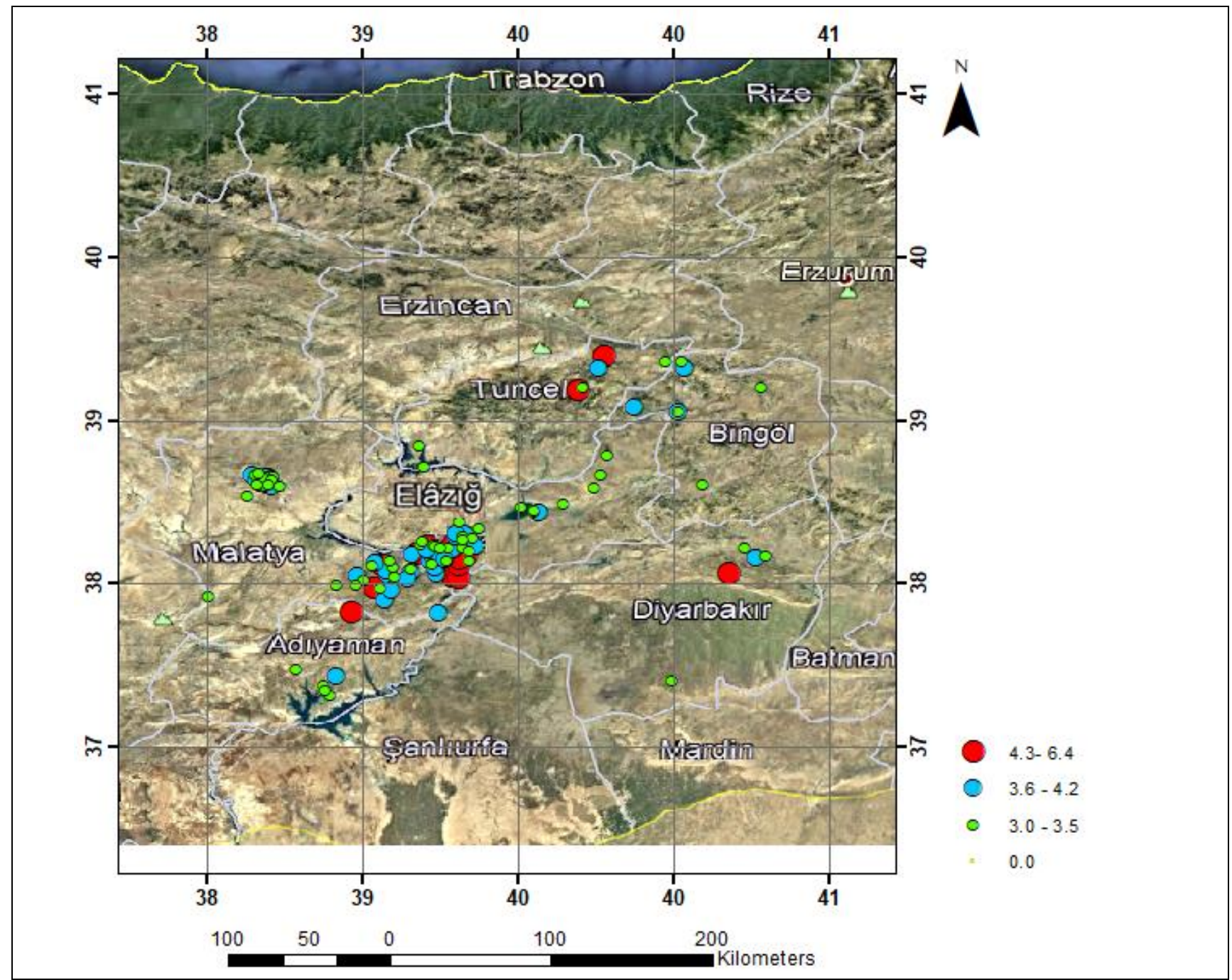

Şekil 2. 3 Ocak 2019-24 Ocak 2020 tarihleri arasında çalışma bölgesinde meydana gelen depremler ve artçı şok aktivitesi Mw>3

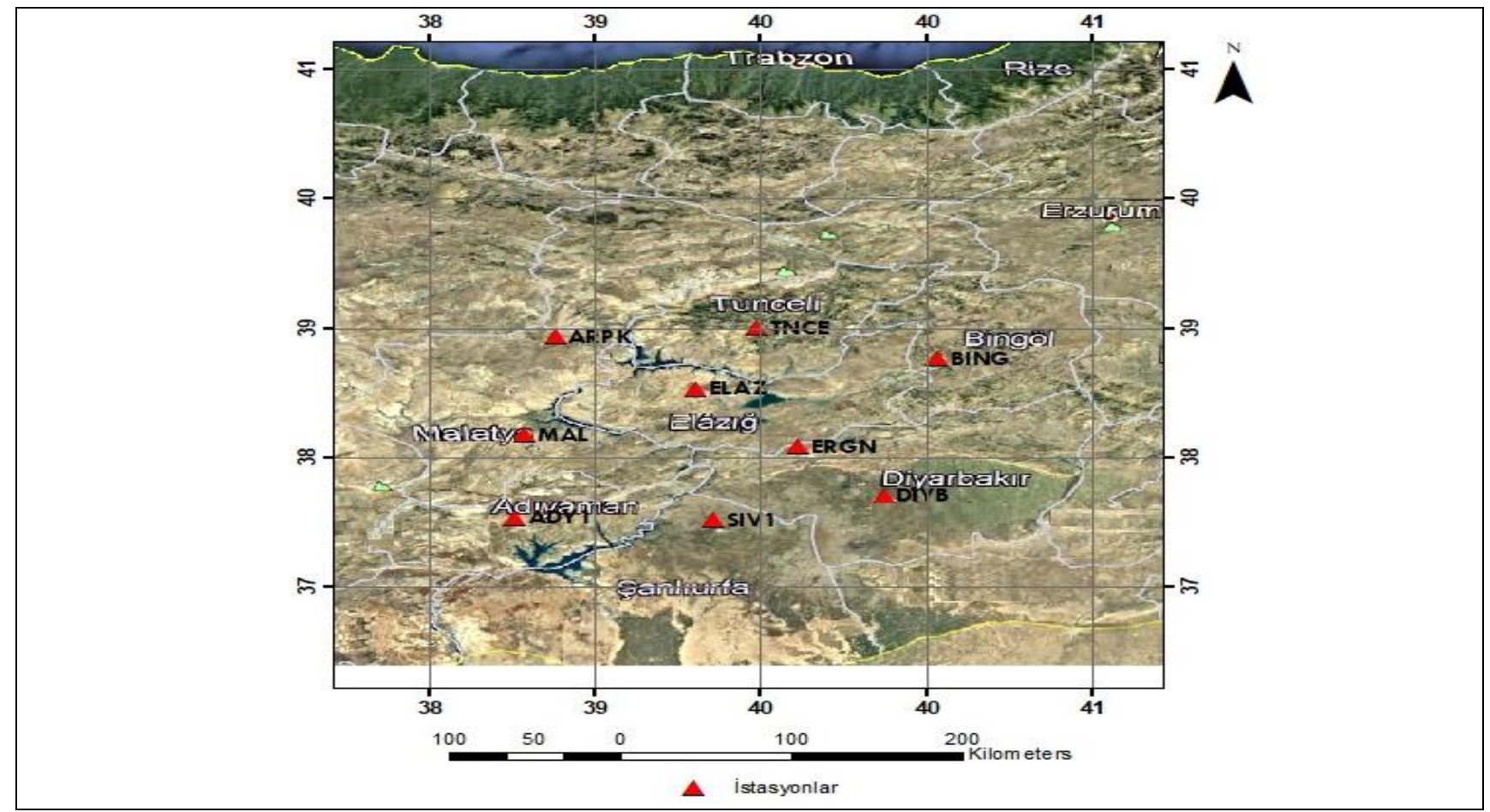

Şekil 3. Çalışma alanındaki TUSAGA-Aktif istasyonlarının dağılımı 
Tablo 1. Meydana gelen depremlerin TUSAGA-Aktif istasyonlarına uzaklıkları (km)

\begin{tabular}{|c|c|c|c|}
\hline İstasyon Adı & $\begin{array}{c}\text { 04 Nisan } 2019 \\
(5.2 \mathrm{Mw})\end{array}$ & $\begin{array}{c}27 \text { Arallk } 2019 \\
(4.8 \mathrm{Mw})\end{array}$ & $\begin{array}{c}24 \text { Ocak 2020 } \\
(6.5 \mathrm{Mw})\end{array}$ \\
\hline ADY1 & 102.2 & 91.3 & 108.8 \\
\hline ARPK & 94.7 & 87.9 & 103.3 \\
\hline BING & 131.7 & 144.7 & 123.8 \\
\hline DIYB & 101.9 & 114.3 & 91.4 \\
\hline ELAZ & 33.0 & 40.3 & 34.2 \\
\hline ERGN & 54.6 & 68.3 & 43.9 \\
\hline MALY & 81.1 & 67.1 & 91.5 \\
\hline SIV1 & 69.2 & 72.7 & 65.0 \\
\hline TNCE & 90.2 & 97.3 & 89.2 \\
\hline
\end{tabular}

Tablo 1'e göre 04 Nisan 2019, 27 Aralık 2019 ve 24 Ocak 2020 tarihlerinde meydana gelen depremlerin merkezlerine en yakın TUSAGA-Aktif istasyonu yaklaşık 30-40 km ile Elazığ ilinde bulunan ELAZ istasyonudur.

\section{YÖNTEM}

\subsection{TUSAGA-Aktif İstasyon Verilerinin $\theta^{2}$ Ölçütü Yöntemi İle Deformasyon Analizi}

$\theta^{2}$ Ölçütü yönteminde, ilk olarak tüm periyotlardaki jeodezik ölçüler ayrı ayrı serbest olarak dengelenir. Dengeleme sonucunda, dengeli koordinat vektörleri $\left(x_{1}, x_{2}, \ldots\right)$ ve bilinmeyenlerin ters ağırlık matrisleri $\left(Q_{x_{1} x_{1}}, Q_{x_{2} x_{2}}, \ldots\right)$ hesaplanır. İki periyot için $d$ fark vektörü ve bu vektöre ait kofaktör matrisi $Q_{d d}$,

$$
\begin{aligned}
& d=x_{2}-x_{1} \\
& Q_{d d}=Q_{x_{1} x_{1}}+Q_{x_{2} x_{2}}
\end{aligned}
$$

olarak hesaplanır. Düzeltmelerin ağırlıklı kareleri toplamına etkisi olan $\theta^{2}$ Ölçütü,

$$
\theta^{2}=d^{T} Q_{d d}^{+} d
$$

biçiminde hesaplanır. Ağın geometrik şeklinin ve datum parametrelerinin her iki ölçüm periyodunda da aynı kaldığı durumlarda $Q_{d d}$ 'nin rangı,

$$
h=\operatorname{rang}\left(Q_{d d}\right)=u_{k}-d p
$$

eşitliği ile hesaplanır. Burada $u_{k}$, ağdaki koordinat bilinmeyeni sayısını; $d p$, datum parametreleri sayısını göstermektedir. Her iki ölçü kümesinin ortak standart sapması,

$$
S_{0}^{2}=\frac{v_{1}{ }^{T} P_{1} v_{1}+v_{2}{ }^{T} P_{2} v_{2}}{f_{1}+f_{2}}=\frac{f_{1} m_{0_{1}}^{2}+f_{2} m_{02}^{2}}{f_{1}+f_{2}}
$$

şeklinde elde edilir. Burada $f_{1}$ ve $f_{2}$ sırasıyla 1 . ve 2 . periyotlardaki ölçümlerin dengelemesi sırasında kullanılan serbestlik dereceleri; $m_{0_{1}}^{2}$ ve $m_{0_{2}}^{2}$ ise sırasıyla 1 . ve 2 . periyotlardaki ölçümlerin dengelemesi sonucunda elde edilen varyans değerleridir. Eşdeğerlik testinin test büyüklüğü $(T)$,

$$
T=\frac{\theta^{2}}{s_{0}^{2} h}=\frac{d^{T} Q_{d d}^{+} d}{s_{0}^{2} h}
$$

eşitliği ile hesaplanır. Test büyüklüğü $T, F$ tablo değeri ile karşılaştırılır. $H_{0}$ hipotezi $T<F_{h, f, 1-\alpha}$ olduğu durumda geçerli, $T>F_{h, f, 1-\alpha}$ olduğu durumlarda ise $H_{0}$ hipotezi geçerli değildir. $\mathrm{Bu}$ durumda iki ölçü periyodu arası geçen sürede ağ noktalarının bir ya da birden fazlasında deformasyon olduğuna $(1-\alpha)$ istatistik güven ile karar verilir. Ağda deformasyon olduğu belirlendikten sonra, ağda hareket eden noktalar tek tek belirlenir. Bunun için ağda bulunan bir nokta her seferinde hareketli, diğer noktalar ise sabit olduğu varsayımı ile nokta sayısı kadar $\theta^{2}$ ölçütü değeri hesaplanır. Fark vektörü $d$ ve kovaryans matrisi $Q_{d d}$,

$$
\begin{gathered}
d=\left|\begin{array}{l}
d_{F} \\
d_{B}
\end{array}\right| \\
Q_{d d}=\left|\begin{array}{ll}
Q_{F F} & Q_{F B} \\
Q_{B F} & Q_{B B}
\end{array}\right|
\end{gathered}
$$

eşitlikleri ile elde edilir. Burada $B$ indisi, hareketli noktaları; $F$ indisi, sabit noktaları göstermektedir. $P_{d d}$ ağırlık matrisi,

$$
P_{d d}=Q_{d d}^{+}=\left|\begin{array}{ll}
P_{F F} & P_{F B} \\
P_{B F} & P_{B B}
\end{array}\right|
$$

eşitliği ile yani $Q_{d d}$ matrisinin tersi alınarak elde edilir. $B$ ile hareketli nokta olarak alınan nokta her adımda $d_{B}$ alt vektör olarak yazılır ve ağ nokta sayısı kadar aykırılık etkisi hesaplanır. Alt matrisler Gauss yöntemi ile indirgenerek,

$$
\begin{aligned}
& \bar{d}_{B}=d_{B}-P_{B B}^{-1} P_{B F} d_{F} \\
& \bar{P}_{F F}=P_{F F}-P_{F B} P_{B B}{ }^{-1} P
\end{aligned}
$$

hesaplanır. $\theta^{2}$ ölçütü değeri,

$$
\theta^{2}=d^{T} Q_{d d}^{+} d=d_{F}{ }^{T} \bar{P}_{F F} d_{F}+\bar{d}_{B}{ }^{T} \bar{P}_{B B} \bar{d}_{B}
$$

$d_{F}{ }^{T} \bar{P}_{F F} d_{F}$ sabit olduğu varsayllan noktaya ait aykırılık, $\bar{d}_{B}{ }^{T} \bar{P}_{B B} \bar{d}_{B}$ hareketli olduğu varsayılan her 
noktaya ait aykırılık olarak bağımsız iki bileşene ayrilır.

$$
\left(\theta^{2}\right)_{i}=\left(\bar{d}_{B}{ }^{T} P_{B B} \bar{d}_{B}\right)_{i} \quad i=1,2, \ldots, n
$$

Burada $n$, nokta sayısıdır. Toplam aykırılık payı en büyük olan $\left(\theta^{2}\right)_{\text {mak }}=$ maksimum $\left(\left(\theta^{2}\right)_{i}\right)$ olan noktada, $1-\alpha$ istatistik güven ile deformasyon olduğuna karar verilir. Ağda hareketli başka nokta veya noktalar bulunup bulunmadığını belirlemek için $d$ ve $Q_{d d}$ 'ye bir $S$ dönüşümü yapılarak geriye kalan $(n-1)$ noktadan yararlanarak yeni bir datum verilir. $d$ ve $Q_{d d}$ ' de hareketli noktaya ait elemanlar en son satır ve sütunlara atılır. $G$ matrisi ile $S$ dönüşüm matrisi,

$$
S_{i}=I-G G^{T}
$$

eşitliği ile elde edilir. $d$ ve $Q_{d d}$ matrisi,

$$
\begin{aligned}
& d_{i}=S_{i} d \\
& Q_{d d_{i}}=S_{i} Q_{d d} S_{i}^{T}
\end{aligned}
$$

biçiminde dönüştürülür. $i$ dönüşümden sonra fark vektörü ve bunun ters ağırlık matrisi,

$$
\begin{aligned}
& d_{i}=\left|\begin{array}{l}
d_{D} \\
d_{N}
\end{array}\right|=S_{i}\left|\begin{array}{l}
d_{F} \\
d_{B}
\end{array}\right|=S_{i} d \\
& Q_{d d_{i}}=\left|\begin{array}{ll}
Q_{D D} & Q_{D N} \\
Q_{N D} & Q_{N N}
\end{array}\right|
\end{aligned}
$$

şeklinde alt matrislere ayrılır. Burada $D$ indisi, datum noktalarını; $N$ indisi, datum dönüşümüne katılmayan noktaları; $d_{N}$, toplam aykırlıktaki payları en büyük olan $\left(\theta^{2}\right)_{\text {mak }}$ noktalarına ait $d_{\mathrm{B}}$ değerinin sonraki değerini göstermektedir. $i$ belirleme adımından sonra kalan aykırılık,

$$
\left(\theta^{2}\right)_{\text {kalan }}=d_{D}^{T} Q_{D D}^{+} d_{D}
$$

eşitliği ile hesaplanır. Test büyüklüğü,

$$
T_{D}=\frac{\left(\theta^{2}\right)_{\text {kalan }}}{\widehat{\sigma}_{0}^{2} h_{D}}>F_{h_{D}, f_{D, 1-\alpha}}
$$

olduğu durumda ağda hareketli nokta vardır. Burada yeni hareketli nokta, yukarıdaki işlemler tekrar edilerek belirlenir. Son bir $S$ dönüşümü ile ağda hareketsiz kalan noktalar $P_{D}$, hareketsiz olduğu tespit edilen noktalar $P_{N}$ ve deformasyon büyüklükleri $d_{N}$ elde edilir (Öztürk ve Şerbetçi,
1992; Kayıkçı ve Yalçınkaya, 2015; Yalçınkaya, 2003).

Her periyottaki (03 Ocak 2019, 05 Nisan 2019, 28 Aralık 2019, 25 Ocak 2020) GNSS p̈łç̈̈leri ayrı ayrı serbest dengelenmiștir. Ardından noktaların kartezyen koordinatları ve varyans-kovaryans matrisleri elde edilmiştir. Bu veriler ile 03 Ocak 2019-05 Nisan 2019, 03 Ocak 2019-28 Aralık 2019 ve 03 Ocak 2019-25 Ocak 2020 periyotlarındaki deformasyonlar $\theta^{2}$ ölçütü yöntemi ile hesaplanmıştır (Tablo 2-3-4).

Tablo 2-3-4 incelendiğinde her iterasyonda test büyüklüğü $T^{\prime}$ ye karşılık gelen $\mathrm{F}$ tablo değeri karşılaştırılarak $T$ değerinin büyük olması durumunda yapılan karşılaştırmalarda deformasyon olduğuna karar verilmiştir. $\theta^{2}$ Ölçütü yöntemi ile kartezyen koordinat sisteminde 03 Ocak 2019 periyotu referans alınarak yapılan deformasyon analizine göre; 05 Nisan 2019 periyodu ile arasında geçen sürede DIYB, MALY, SIV1 ve TNCE TUSAGAAktif istasyonlarında (Tablo 2), 28 Aralık 2019 periyodu ile arasında geçen sürede BING, DIYB, ELAZ, ERGN, MALY ve TNCE TUSAGA-Aktif istasyonlarında (Tablo 3), 25 Ocak 2020 periyodu ile arasında geçen sürede BING istasyonu hariç diğer tüm istasyonlarda (Tablo 4) hareketlerin anlamlı olduğu belirlenmiştir.

$\theta^{2}$ ölçütü yöntemine göre TUSAGA-Aktif istasyonlarını 03 Ocak 2019 referans periyodu seçilerek 03 Ocak 2019-05 Nisan 2019, 03 Ocak 2019-28 Aralı 2019 ve 03 Ocak 2019-25 Ocak 2020 periyotları arası kartezyen koordinat sisteminde hesaplanan deformasyon miktarları, lokal toposentrik koordinat sistemine dönüștürülerek Şekil 4 'de verilmiştir.

\subsection{TUSAGA-Aktif İstasyon Verilerinin IWST Yöntemi İle Deformasyon Analizi}

İteratif Ağırlıklı Benzerlik Dönüşümü (IWST) yöntemi Kanada'nı New Brunswick Üniversitesi'nde Chen (1983) tarafindan geliştirilmiş olup, robust yöntemler kategorisinde yer almaktadır. IWST yöntemi ile deformasyon analiz işlemi üç ana başlık altında verilebilir. İlk aşamada, her bir periyottaki jeodezik ölçüler ayrı ayrı serbest dengelenir. Dengeleme sonucunda koordinatlar, vektörleri $\left(x_{1}, x_{2}, \ldots\right) \quad$ ve bilinmeyenlerin ters ağırlık matrisleri $\left(Q_{x_{1} x_{1}}\right.$, $\left.Q_{x_{2} x_{2}}, \ldots\right)$ hesaplanır. İki periyot için $d$ fark vektörü ve $d$ fark vektörüne ait kovaryans matrisi $Q_{d d}$ sirasiyla (1) ve (2) eşitlikleri ile hesaplanır.

Tablo 2. 03 Ocak 2019 ile 05 Nisan 2019 periyotları arası $\theta^{2}$-Ölçütü ile deformasyon analizi

\begin{tabular}{|c|c|c|c|c|c|c|c|}
\hline \multirow{2}{*}{ Adım } & \multicolumn{2}{|c|}{ Global Test } & \multicolumn{5}{|c|}{ Hareketli Noktalar ve Hareket Büyüklükleri } \\
\cline { 2 - 9 } & $\begin{array}{c}\text { Test } \\
\text { Büyüklüğü (T) }\end{array}$ & $\begin{array}{c}\boldsymbol{F} \\
\text { Tablo }\end{array}$ & $\boldsymbol{\theta}_{\text {maksimum }}^{\mathbf{2}}$ & $\begin{array}{c}\text { Hareketli } \\
\text { Nokta }\end{array}$ & $\begin{array}{c}\boldsymbol{d}_{\boldsymbol{x}} \\
(\mathbf{c m})\end{array}$ & $\begin{array}{c}\boldsymbol{d}_{\boldsymbol{y}} \\
(\mathbf{c m})\end{array}$ & $\begin{array}{c}\boldsymbol{d}_{\boldsymbol{z}} \\
(\mathbf{c m})\end{array}$ \\
\hline $\mathbf{1}$ & 4.62 & 1.81 & 87.04 & TNCE & -1.21 & -0.61 & -1.53 \\
\hline $\mathbf{2}$ & 3.10 & 1.86 & 35.71 & MALY & 0.77 & 0.34 & 1.02 \\
\hline $\mathbf{3}$ & 2.06 & 1.92 & 23.10 & DIYB & 0.33 & 0.52 & 0.59 \\
\hline $\mathbf{4}$ & 2.15 & 1.99 & 13.07 & SIV1 & -0.61 & -0.43 & -0.04 \\
\hline
\end{tabular}


Tablo 3. 03 Ocak 2019 ile 28 Aralık 2019 periyotları arası $\theta^{2}$-Ölçütü ile deformasyon analizi

\begin{tabular}{|c|c|c|c|c|c|c|c|}
\hline \multirow{2}{*}{ Adım } & \multicolumn{2}{|c|}{ Global Test } & \multicolumn{4}{|c|}{ Hareketli Noktalar ve Hareket Büyüklükleri } \\
\cline { 2 - 9 } & $\begin{array}{c}\text { Test } \\
\text { Büyüklüğü } \\
(\boldsymbol{T})\end{array}$ & $\begin{array}{c}\boldsymbol{F} \\
\text { Tablo }\end{array}$ & $\boldsymbol{\theta}_{\text {maksimum }}^{\mathbf{2}}$ & $\begin{array}{c}\text { Hareketli } \\
\text { Nokta }\end{array}$ & $\begin{array}{c}\boldsymbol{d}_{\boldsymbol{x}} \\
(\mathbf{c m})\end{array}$ & $\begin{array}{c}\boldsymbol{d}_{\boldsymbol{y}} \\
(\mathbf{c m})\end{array}$ & $\begin{array}{c}\boldsymbol{d}_{\boldsymbol{z}} \\
(\mathbf{c m})\end{array}$ \\
\hline $\mathbf{1}$ & 4.46 & 1.81 & 168.27 & MALY & -1.60 & -1.54 & -1.24 \\
\hline $\mathbf{2}$ & 3.84 & 1.86 & 82.86 & BING & 0.91 & 1.03 & 0.62 \\
\hline $\mathbf{3}$ & 4.34 & 1.92 & 86.08 & TNCE & 1.44 & 0.69 & 0.78 \\
\hline $\mathbf{4}$ & 4.00 & 1.99 & 70.10 & DIYB & 0.50 & 1.12 & 1.19 \\
\hline $\mathbf{5}$ & 4.16 & 2.10 & 44.66 & ERGN & 0.40 & 1.00 & 0.77 \\
\hline $\mathbf{6}$ & 3.03 & 2.27 & 21.91 & ELAZ & 1.04 & 0.50 & 0.39 \\
\hline
\end{tabular}

Tablo 4. 03 Ocak 2019 ile 25 Ocak 2020 periyotları arası $\theta^{2}$-Ölçütü ile deformasyon analizi

\begin{tabular}{|c|c|c|c|c|c|c|c|}
\hline \multirow{2}{*}{ Adım } & \multicolumn{2}{|c|}{ Global Test } & \multicolumn{5}{c|}{ Hareketli Noktalar ve Hareket Büyüklükleri } \\
\cline { 2 - 9 } & $\begin{array}{c}\text { Test } \\
\text { Büyüklüğü } \\
(\boldsymbol{T})\end{array}$ & $\begin{array}{c}\boldsymbol{F} \\
\text { Tablo }\end{array}$ & $\boldsymbol{\theta}_{\text {maksimum }}^{\mathbf{2}}$ & $\begin{array}{c}\text { Hareketli } \\
\text { Nokta }\end{array}$ & $\begin{array}{c}\boldsymbol{d}_{\boldsymbol{x}} \\
\text { (cm) }\end{array}$ & $\begin{array}{c}\boldsymbol{d}_{\boldsymbol{y}} \\
(\mathbf{c m})\end{array}$ & $\begin{array}{c}\boldsymbol{d}_{\boldsymbol{z}} \\
\text { (cm) }\end{array}$ \\
\hline $\mathbf{1}$ & 97.74 & 1.81 & 3446.32 & ELAZ & 5.79 & 1.24 & -2.13 \\
\hline $\mathbf{2}$ & 34.20 & 1.86 & 977.20 & ERGN & -1.92 & 1.33 & -1.08 \\
\hline $\mathbf{3}$ & 27.51 & 1.92 & 575.89 & MALY & 1.62 & -1.30 & 1.37 \\
\hline $\mathbf{4}$ & 19.60 & 1.99 & 389.67 & TNCE & 2.86 & 1.47 & 1.32 \\
\hline $\mathbf{5}$ & 19.28 & 2.10 & 195.32 & SIV1 & -2.16 & -1.05 & -1.31 \\
\hline $\mathbf{6}$ & 22.27 & 2.27 & 122.36 & DIYB & -2.52 & -0.65 & -2.29 \\
\hline $\mathbf{7}$ & 18.07 & 2.56 & 22.75 & ADY1 & -2.58 & -1.86 & -2.27 \\
\hline $\mathbf{8}$ & 8.87 & 3.28 & 11.34 & ARPK & 0.70 & -0.51 & 0.38 \\
\hline
\end{tabular}
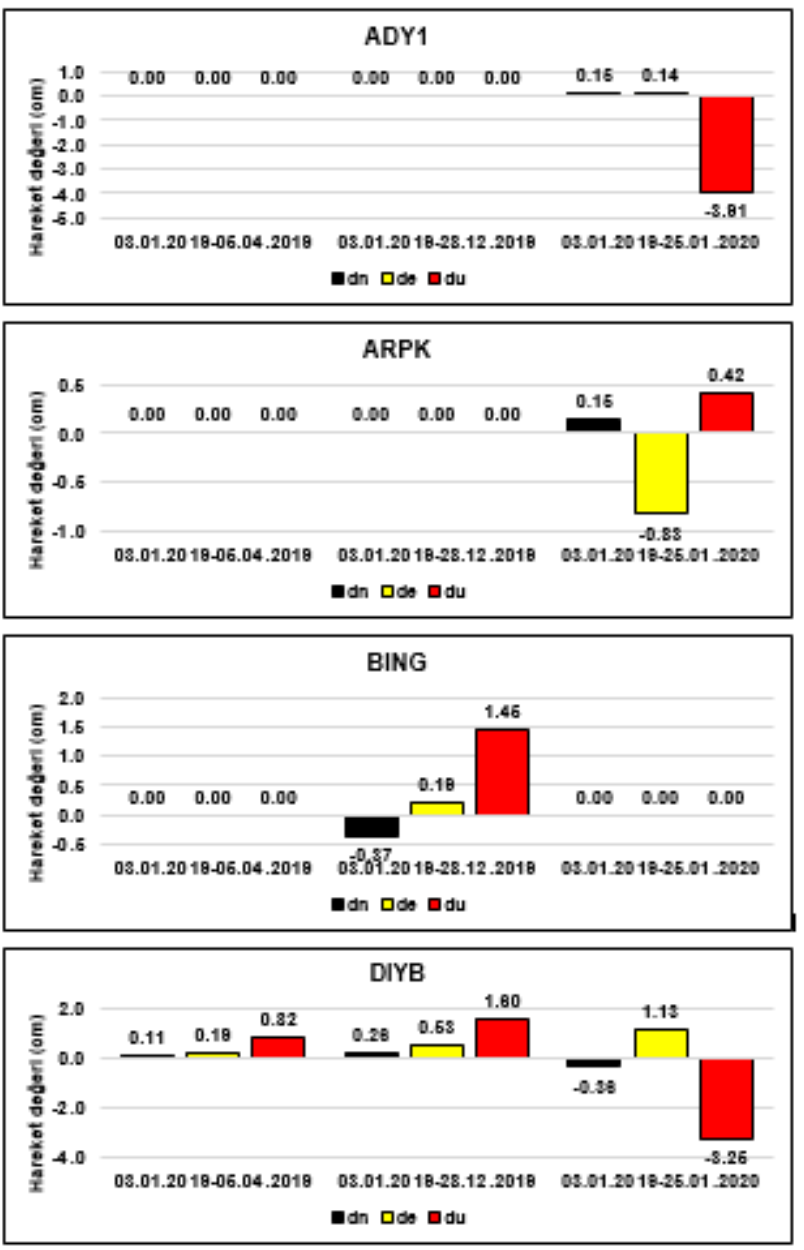
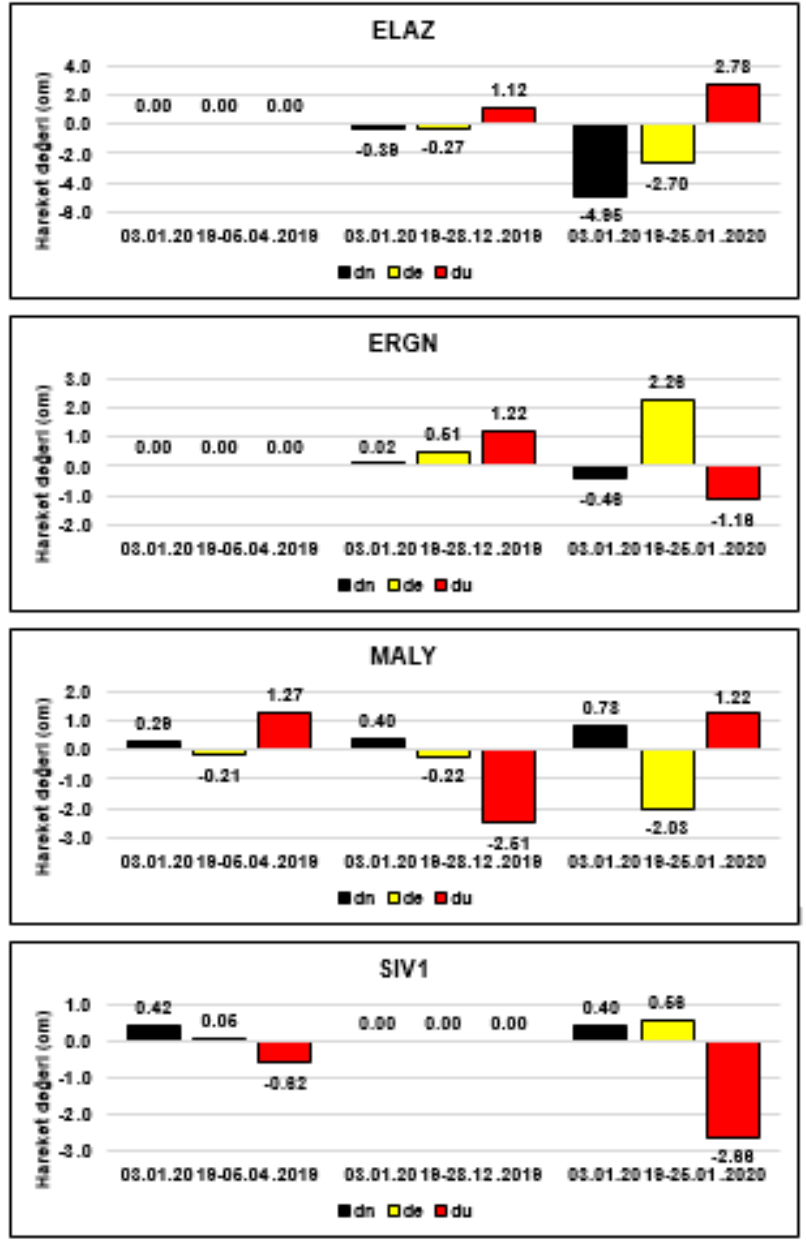


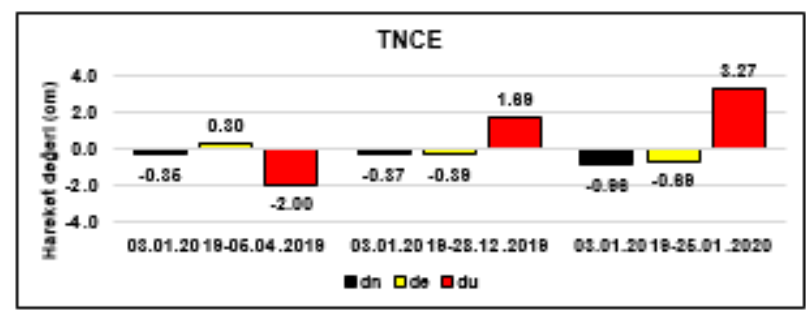

Şekil 4. $\theta^{2}$ ölçütü yöntemine göre belirlenen deformasyonların lokal toposentrik sistemdeki hareket miktarları

İkinci aşamada, iki periyota ait koordinat vektörlerinin farklı datumlarda olduğu varsayımı yapllarak, $x_{2}$ koordinat vektörü, $x_{1}$ koordinat vektörünün hesaplandığ ${ }^{\prime}$ datum sistemine $S$ dönüşüm matrisi,

$$
S^{(k)}=I-H\left(H^{T} W^{(k)} H\right)^{-1} H^{T} W^{(k)}
$$

yardımıyla indirgenmelidir. IWST,

$$
\begin{aligned}
& d^{(k)}=S^{(k)}\left(x_{2}-x_{1}\right) \\
& Q_{d d}^{(k)}=S^{(k)} Q_{d d}\left(S^{(k)}\right)^{T} \\
& W^{(k+1)}=\operatorname{diag}\left(\ldots, w_{i}{ }^{(k+1)}, \ldots\right), \\
& w_{i}^{\left({ }^{(k+1)}\right.}=1 / d_{i}{ }^{(k)}
\end{aligned}
$$

iteratif forma sahiptir. Burada $k$, iterasyon sayısını; $W^{(k+1)}$, ağırlık matrisini göstermektedir. IWST ile her iterasyonda ağırlıklar yeniden hesaplanır. İterasyon işlemi belirlenen durdurma kriterine göre devam eder (Ör: $\left|d^{(k+1)}-d^{(k)}\right|<$ $0.0001 \mathrm{~m}$ ). İlk iterasyonda ağırlık matrisi $W^{(k)}=I$ birim matrisi olarak alınır. Üçüncü aşamada, noktaların hareketlerinin anlamlı olup olmadığı tek noktalı test ile tespit edilir. Tek noktalı teste göre,

$$
T_{i}=\frac{\left(d_{i}\right)^{T}\left(Q_{d d}\right)^{-1} d_{i}}{s_{0}^{2} h} \sim F_{h, f, 1-\alpha}
$$

şeklinde hesaplanır. $T_{i}$ test değeri $F$-tablo değeri ile karşılaştırılır. Eğer $T_{i} \geq F_{h, f, 1-\alpha}$ olduğu durumda $i$ 'inci noktanın hareketli olduğuna, tersi durumda noktanın hareketsiz olduğuna karar verilir (Caspary, 1987; Chen, 1983; Setan ve Singh, 2001; Taşçı, 2010).

Her periyottaki (03 Ocak 2019, 05 Nisan 2019, 28 Aralık 2019, 25 Ocak 2020) GNSS ölçüleri ayrı ayrı serbest dengelenmiștir. Ardından noktaların kartezyen koordinatları ve varyans-kovaryans matrisleri elde edilmiştir. Bu veriler ile 03 Ocak

\begin{tabular}{|c|c|c|c|c|c|c|c|c|}
\hline \multirow[b]{2}{*}{$\begin{array}{c}\text { Nokta } \\
\text { Adı }\end{array}$} & \multicolumn{3}{|c|}{ Test Büyüklükleri } & \multirow[b]{2}{*}{$F$-tablo } & \multicolumn{3}{|c|}{ Hareket Büyüklükleri } & \multirow[b]{2}{*}{ Karar } \\
\hline & $T_{x}$ & $T_{y}$ & $T_{z}$ & & $\begin{array}{c}d_{x} \\
(\mathrm{~cm})\end{array}$ & $\begin{array}{c}d_{y} \\
(\mathrm{~cm})\end{array}$ & $\begin{array}{c}d_{z} \\
(\mathrm{~cm})\end{array}$ & \\
\hline ADY1 & 0.83 & 0.17 & 0.01 & 2.71 & 0.52 & -0.19 & 0.05 & Hareketsiz \\
\hline ARPK & 0.49 & 0.17 & 1.19 & 2.71 & -0.39 & -0.22 & -0.60 & Hareketsiz \\
\hline BING & 0.04 & 0.65 & 0.12 & 2.71 & 0.11 & 0.36 & 0.17 & Hareketsiz \\
\hline DIYB & 0.47 & 1.13 & 1.58 & 2.71 & 0.37 & 0.55 & 0.63 & Hareketsiz \\
\hline ELAZ & 1.24 & 0.02 & 0.00 & 2.71 & 0.40 & -0.05 & 0.01 & Hareketsiz \\
\hline ERGN & 0.05 & 0.55 & 0.21 & 2.71 & -0.08 & 0.25 & 0.16 & Hareketsiz \\
\hline MALY & 4.27 & 1.15 & 8.83 & 2.71 & 0.92 & 0.41 & 1.21 & Hareketli \\
\hline SIV1 & 1.82 & 1.43 & 0.05 & 2.71 & -0.62 & -0.49 & -0.10 & Hareketsiz \\
\hline TNCE & 7.90 & 2.31 & 12.40 & 2.71 & -1.21 & -0.61 & -1.53 & Hareketli \\
\hline
\end{tabular}
2019-05 Nisan 2019, 03 Ocak 2019-28 Aralık 2019 ve 03 Ocak 2019-25 Ocak 2020 periyotlarındaki

\begin{tabular}{|c|c|c|c|c|c|c|c|c|}
\hline \multirow[b]{2}{*}{$\begin{array}{c}\text { Nokta } \\
\text { Adı }\end{array}$} & \multicolumn{3}{|c|}{ Test Büyüklükleri } & \multirow[b]{2}{*}{$F$-tablo } & \multicolumn{3}{|c|}{ Hareket Büyüklükleri } & \multirow[b]{2}{*}{ Karar } \\
\hline & $T_{x}$ & $T_{y}$ & $T_{z}$ & & $\begin{array}{c}d_{x} \\
(\mathrm{~cm})\end{array}$ & $\begin{array}{c}d_{y} \\
(\mathrm{~cm})\end{array}$ & $\begin{array}{c}d_{z} \\
(\mathrm{~cm})\end{array}$ & \\
\hline ADY1 & 0.85 & 0.95 & 0.77 & 2.71 & -0.61 & -0.53 & -0.50 & Hareketsiz \\
\hline ARPK & 0.33 & 2.16 & 1.76 & 2.71 & -0.38 & -0.94 & -0.84 & Hareketsiz \\
\hline BING & 2.84 & 5.07 & 1.86 & 2.71 & 1.11 & 1.22 & 0.78 & Hareketli \\
\hline DIYB & 0.23 & 2.67 & 3.56 & 2.71 & 0.33 & 1.05 & 1.12 & Hareketli \\
\hline ELAZ & 2.56 & 0.01 & 0.06 & 2.71 & 0.67 & -0.04 & -0.10 & Hareketsiz \\
\hline ERGN & 0.09 & 3.20 & 1.44 & 2.71 & 0.13 & 0.71 & 0.47 & Hareketli \\
\hline MALY & 9.65 & 11.27 & 6.92 & 2.71 & 1.60 & -1.54 & -1.24 & Hareketli \\
\hline SIV1 & 4.63 & 1.82 & 1.18 & 2.71 & -1.15 & -0.65 & -0.53 & Hareketli \\
\hline TNCE & 8.65 & 2.32 & 2.88 & 2.71 & 1.51 & 0.73 & 0.85 & Hareketli \\
\hline
\end{tabular}
deformasyonlar IWST yöntemi ile hesaplanmıştır (Tablo 5-6-7).

Tablo 5. 03 Ocak 2019 ile 05 Nisan 2019 periyotları arası IWST Yöntemi ile deformasyon analizi

Tablo 6. 03 Ocak 2019 ile 28 Aralık 2019 periyotları arası IWST Yöntemi ile deformasyon analizi 
Tablo 5-6-7 incelendiğinde her iterasyonda test büyüklüğü $T^{\prime}$ ye karşılık gelen $\mathrm{F}$ tablo değeri karşılaștırılarak $T$ değerinin büyük olması durumunda yapılan karşılaștırmalarda deformasyon olduğuna karar verilmiştir. IWST yöntemi ile kartezyen koordinat sisteminde 03 Ocak 2019 periyotu referans alınarak yapilan deformasyon analizine göre; 05 Nisan 2019 periyodu ile arasında geçen sürede MALY ve TNCE TUSAGA-Aktif istasyonlarında (Tablo 5), 28 Aralık 2019 periyodu ile arasında geçen sürede BING, DIYB, ERGN, MALY ve TNCE TUSAGA-Aktif istasyonlarında (Tablo 6), 25 Ocak 2020 periyodu ile arasında geçen sürede tüm istasyonlarda (Tablo 7) hareketlerin anlamlı olduğu belirlenmiștir.

Tablo 7. 03 Ocak 2019 ile 25 Ocak 2020 periyotları arası IWST Yöntemi ile deformasyon analizi

\begin{tabular}{|c|c|c|c|c|c|c|c|c|}
\hline \multirow[b]{2}{*}{$\begin{array}{c}\text { Nokta } \\
\text { Adı }\end{array}$} & \multicolumn{3}{|c|}{ Test Büyüklükleri } & \multirow[b]{2}{*}{$F$-tablo } & \multicolumn{3}{|c|}{ Hareket Büyüklükleri } & \multirow[b]{2}{*}{ Karar } \\
\hline & $T_{x}$ & $T_{y}$ & $T_{z}$ & & $\begin{array}{c}d_{x} \\
(\mathrm{~cm})\end{array}$ & $\begin{array}{c}d_{y} \\
(\mathrm{~cm})\end{array}$ & $\begin{array}{c}d_{z} \\
(\mathrm{~cm})\end{array}$ & \\
\hline ADY1 & 15.98 & 12.46 & 5.11 & 2.71 & -2.49 & -1.81 & -1.25 & Hareketli \\
\hline ARPK & 11.01 & 0.63 & 17.48 & 2.71 & 2.08 & 0.48 & 2.53 & Hareketli \\
\hline BING & 1.21 & 8.35 & 10.38 & 2.71 & 0.68 & 1.50 & 1.78 & Hareketli \\
\hline DIYB & 30.51 & 1.94 & 12.81 & 2.71 & -3.27 & -0.81 & -2.03 & Hareketli \\
\hline ELAZ & 214.62 & 11.58 & 28.61 & 2.71 & 5.79 & 1.24 & -2.13 & Hareketli \\
\hline ERGN & 43.95 & 10.36 & 4.28 & 2.71 & -2.65 & 1.18 & -0.81 & Hareketli \\
\hline MALY & 5.75 & 14.33 & 15.66 & 2.71 & 1.17 & -1.65 & 1.79 & Hareketli \\
\hline SIV1 & 46.71 & 10.38 & 8.59 & 2.71 & -3.46 & -1.48 & -1.38 & Hareketli \\
\hline TNCE & 19.11 & 8.95 & 10.01 & 2.71 & 2.14 & 1.34 & 1.51 & Hareketli \\
\hline
\end{tabular}
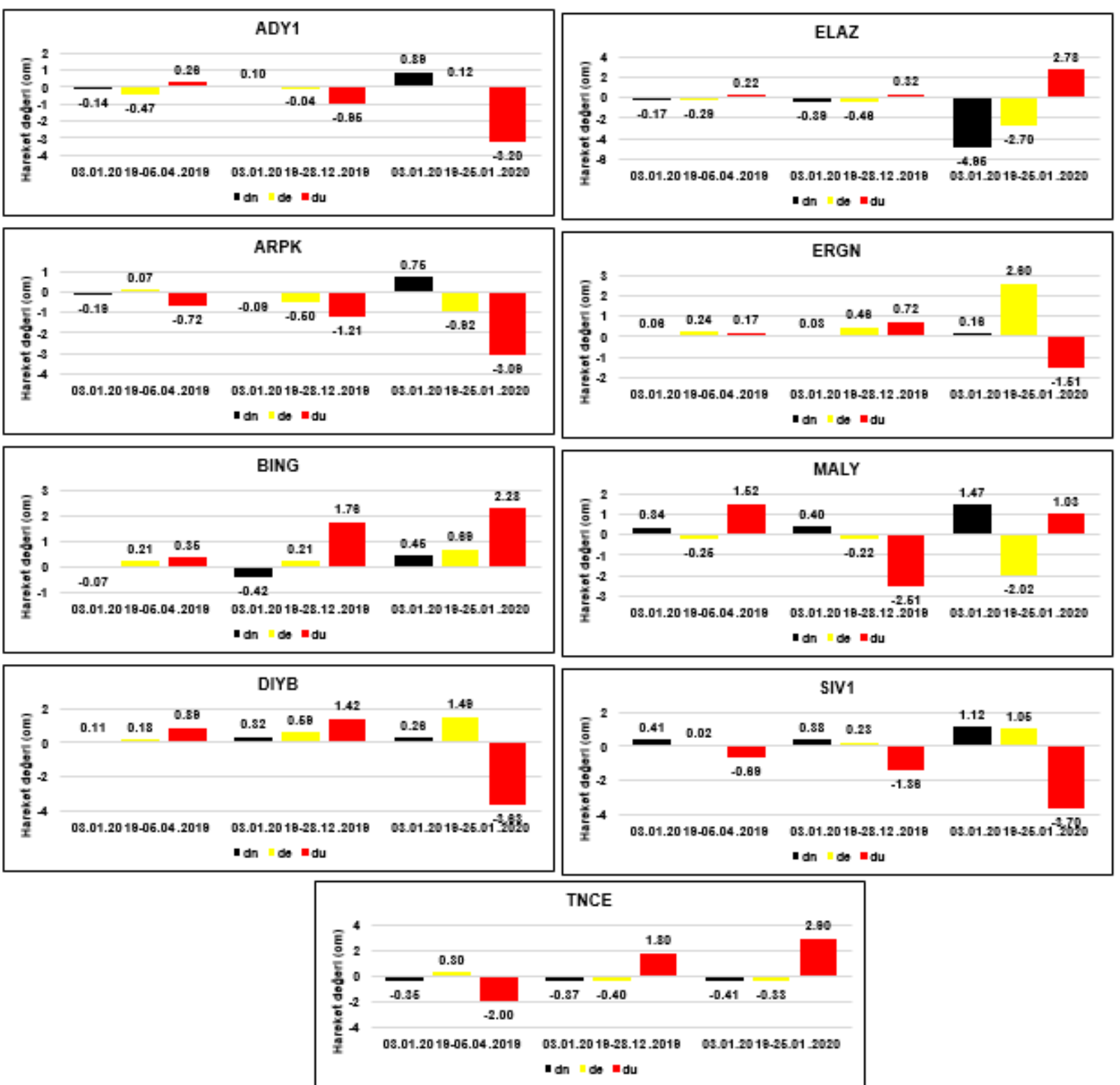

Şekil 5. IWST yöntemine göre belirlenen deformasyonların lokal toposentrik sistemindeki hareket miktarları 
IWST Yöntemine göre TUSAGA-Aktif istasyonlarının 03 Ocak 2019 referans periyodu seçilerek 03 Ocak 2019-05 Nisan 2019, 03 Ocak 2019-28 Aralık 2019 ve 03 Ocak 2019-25 Ocak 2020 periyotları arası kartezyen koordinat sisteminde hesaplanan deformasyon miktarları, lokal toposentrik koordinat sistemine dönüștürülerek Şekil 5 'de verilmiştir.

\section{BULGULAR}

ADY1, ARPK, BING, DIYB, ELAZ, MALY, SIV1 ve TNCE TUSAGA-Aktif istasyonlarından oluşan bölgesel GNSS ağında iki farklı yöntem ile GNSS verileri kullanılarak deformasyon analizi gerçekleștirilmiştir. Deformasyon analizi aşamasından önce TUSAGA-Aktif internet arayüzünden indirilen GNSS verileri serbest ağ dengelemesi yöntemine göre dengelenmiş ve istasyonların koordinat vektörleri ve bu vektörlere ait varyans-kovaryans matrisleri elde edilmiştir. $\theta^{2}$ Ölçütü yöntemine göre yapılmış deformasyon analiz sonuçları tablo 2-3-4'te, IWST yöntemine göre yapılmış deformasyon analiz sonuçları tablo 5-67'de verilmiştir.

Ayrıca her iki yönteme göre yatay ve düşey deformasyon vektörleri çizdirilmiş ve şekil 6-7-8-910 ve 11 'de gösterilmiştir. Yatay ve düşey deformasyon vektörlerini gösteren șekillerde siyah renkli vektörler $\theta^{2}$ Ölçütü yönteminden elde edilen, mavi renkli vektörler ise IWST yönteminden elde edilen hareketleri göstermektedir. Genel olarak incelendiğinde her iki yönteme göre tespit edilen deformasyon miktarlarının birbirleri ile uyumlu olduğu görülmüștür. Buna karşın her iki yöntem arasında farklılıklar da mevcuttur. Bu farklılıklar aşağıda irdelenmiş ve sonuçlar ifade edilmiştir.

03 Ocak 2019-05 Nisan 2019 periyotları arasında $\theta^{2}$ Ölçütü yöntemi, IWST yöntemine göre daha fazla haraketli nokta belirlemiştir. Bu periyot karşılaştırmasında kartezyen koordinat sisteminde IWST yöntemi $6 \mathrm{~mm}$ ve yukarı değerdeki hareketleri belirleyebilirken, $\theta^{2}$ Ölçütü yöntemi $6 \mathrm{~mm}$ harekete sahip olan noktaları hareketli olarak belirlemiştir. $\theta^{2}$ Ölçütü yönteminin daha fazla hareket belirlemesinin nedeni budur. Lokal toposentrik koordinat sisteminde her iki yönteme göre MALY istasyonunda kuzeybatı yönünde yaklaşı 4'mm'lik, TNCE istasyonunda $5 \mathrm{~mm}$ 'lik güneydoğu yönünde hareket belirlenmiştir. DIYB ve SIV1 istasyonlarında yatay hareket yaklașlk 2-4 mm arasında kalmıștır. DIYB ve SIV1 istasyonları kuzeydoğu yönünde hareket etmiștir. $\theta^{2}$ Ölçütü yönteminin DIYB istasyonunu hareketli olarak belirlemesi Kartezyen koordinat sisteminde yaklaşılk $6 \mathrm{~mm}$ ' lik düşey yönlü hareketinden kaynaklanmaktadır.

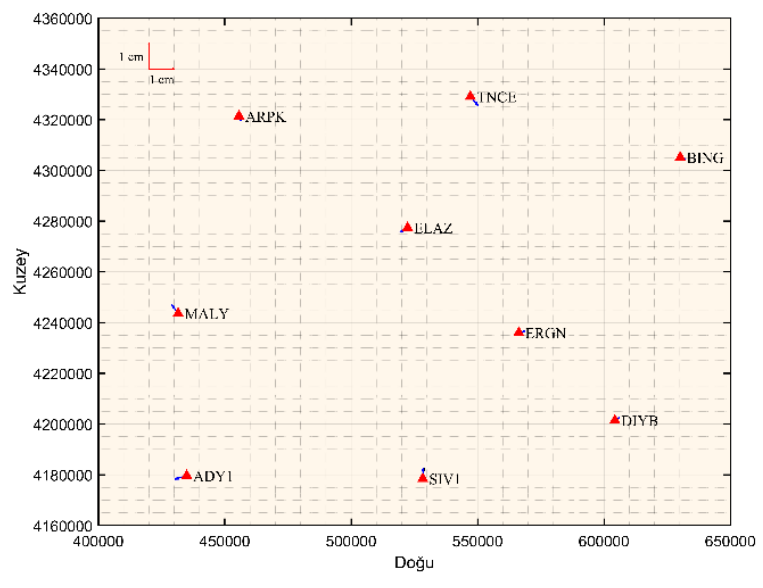

Şekil 6. 03 Ocak 2019 ile 05 Nisan 2020 periyotları arası yatay deformasyon vektörleri

03 Ocak 2019-28 Aralı 2019 periyotları arasında her iki yöntemde aynı sayıda hareketli nokta belirlemiștir. Bu periyot karşılaștırmasında kartezyen koordinat sisteminde her iki yöntemde 6 tane istasyonda hareketin anlamlı olduğunu belirlemiştir. Fakat $\theta^{2}$ Ölçütü yöntemi ELAZ istasyonunu hareketli olarak belirlerken, IWST yöntemi SIV1 istasyonunu hareketli olarak belirlemiștir.

BING istasyonunda güneydoğu yönünde yaklașı 5 mm'lik, yukarı yönde yaklașı 1.5 cm'lik; DIYB istasyonunda kuzeydoğu yönünde yaklaşık 6 mm'lik, yukarı yönde yaklaşık 1.5 cm'lik; ELAZ istasyonunda güneybatı yönünde $6 \mathrm{~mm}$ 'lik; ERGN istasyonunda doğu yönünde yaklaşık $5 \mathrm{~mm}$ 'lik, yukarı yönde yaklaşık $1 \mathrm{~cm}$ 'lik; MALY istasyonunda kuzeybatı yönünde $5 \mathrm{~mm}$ 'lik, aşağı yönde yaklaşı 2.5 cm'lik; SIV1 istasyonunda yaklaşık kuzeydoğu yönünde 4 mm'lik, aşağı yönde yaklaşı $1.5 \mathrm{~cm}$ 'lik; TNCE istasyonunda güneybatı yönünde yaklaşık 5 mm'lik hareket belirlenmiştir. TNCE istasyonunda $\theta^{2}$ Ölçütü yöntemine göre yukarı yönde $1.69 \mathrm{~cm}$ 'lik hareket belirlenirken, IWST yöntemine göre yukarı yönde $2.90 \mathrm{~cm}$ 'lik hareket tespit edilmiştir.

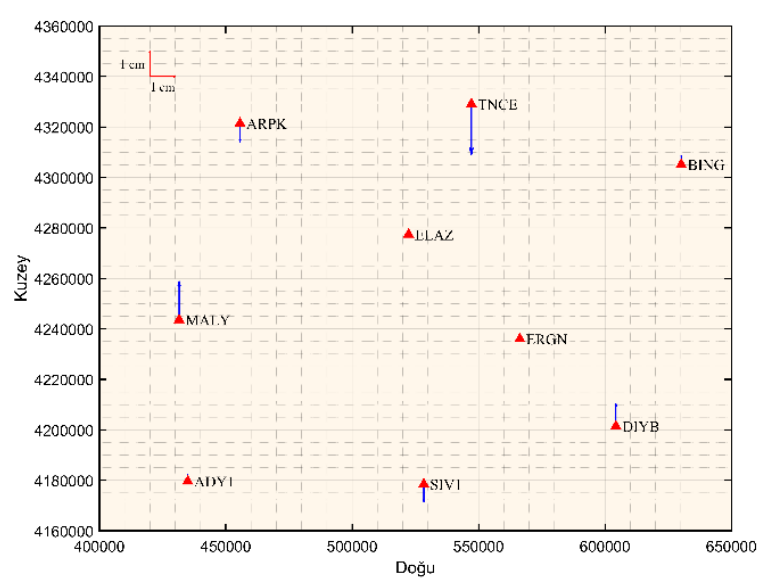

Sekil 7. 03 Ocak 2019 ile 05 Nisan 2020 periyotları arası düşey deformasyon vektörleri 
03 Ocak 2019-25 Ocak 2020 periyotları arasında kartezyen koordinat sisteminde yapilan deformasyon analizleri sonucunda, IWST yöntemi tüm noktalarda hareket belirlerken, $\theta^{2}$ Ölçütü BING istasyonu hariç diğer tüm noktalarda hareket belirlemiştir.

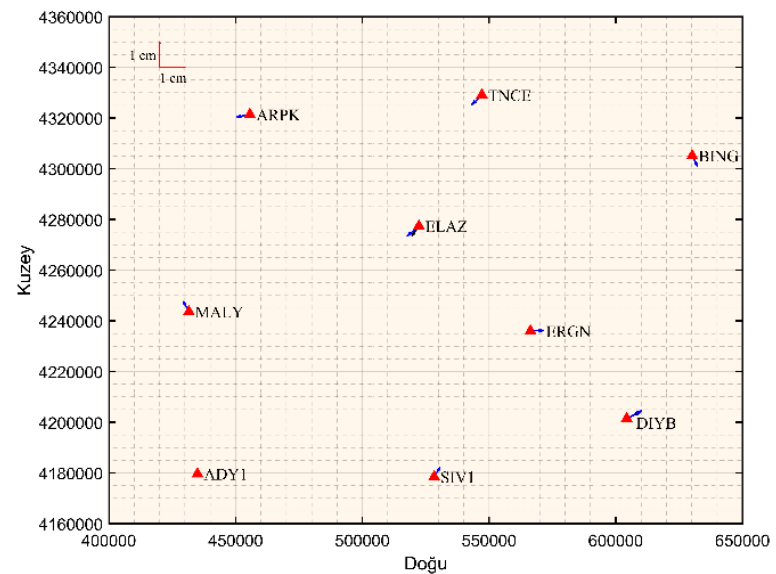

Şekil 8. 03 Ocak 2019 ile 28 Aralık 2020 periyotları arası yatay deformasyon vektörleri

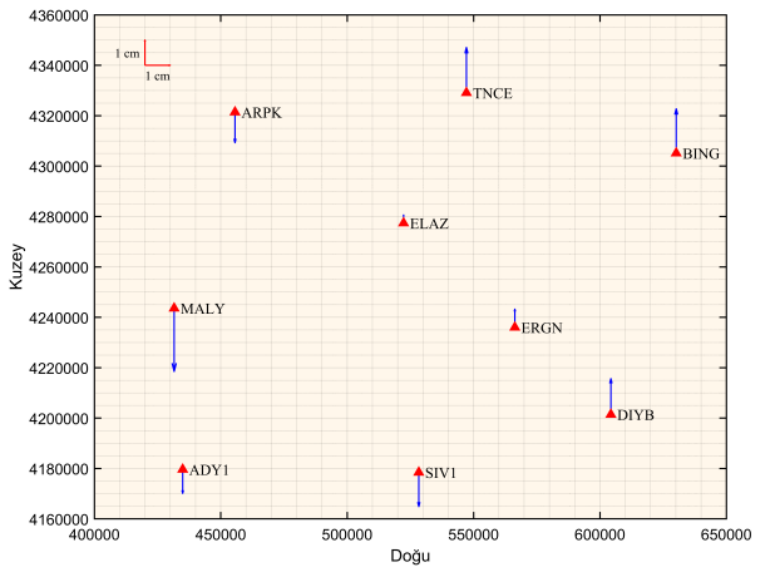

Şekil 9. 03 Ocak 2019 ile 28 Aralık 2020 periyotları arası düşey deformasyon vektörleri

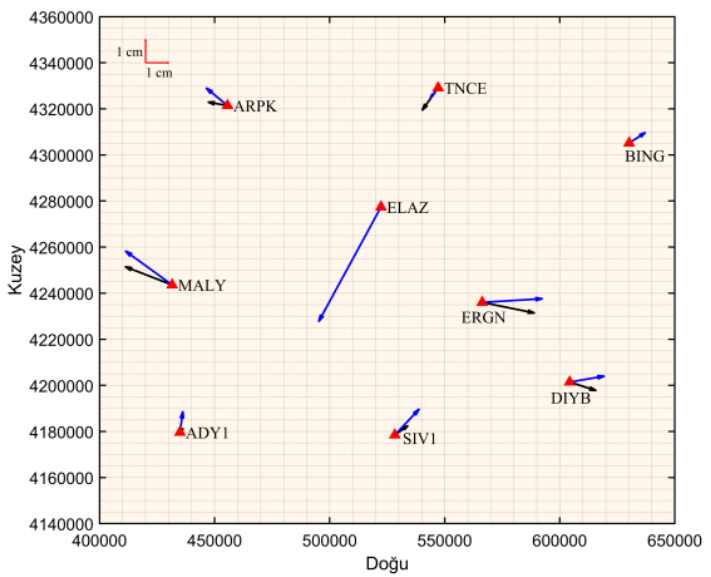

Şekil 10. 03 Ocak 2019 ile 25 Ocak 2020 periyotları arası yatay deformasyon vektörleri

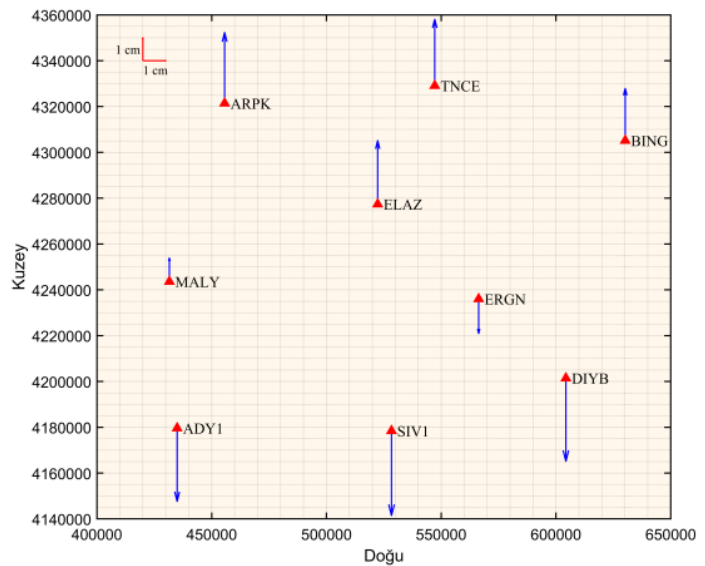

Şekil 11. 03 Ocak 2019 ile 25 Ocak 2020 periyotları arası düșey deformasyon vektörleri

$\mathrm{Bu}$ periyot karşılaştırmasında $\theta^{2}$ Ölçütü yöntemi 8 tane istasyonda hareketlerin anlamlı olduğunu belirlerken, IWST yöntemi bölgesel GNSS ağında bulunan tüm istasyonlardaki hareketleri anlamlı olarak tespit etmiştir. $\theta^{2}$ Ölçütü yöntemiyle yapılan deformasyon araştırmasında her iterasyonda bir noktanın hareketsiz olarak alınması nedeni ile yöntem BING istasyonunda hareket belirlenememiştir. Bu istasyonda IWST yöntemi ile yatay doğrultuda yaklaşık $0.8 \quad \mathrm{~cm}$ 'lik, düșey doğrultuda ise yaklaşık $2 \mathrm{~cm}$ 'lik hareket belirlenmiştir. Diğer istasyonlarda yatay doğrultuda hareket yaklaşık 0.2-5.5 cm arasında, düșey doğrultuda hareket ise mutlak olarak yaklașık 1-3 cm arasında belirlenmiștir.

03 Ocak 2019 ile 25 Ocak 2020 periyotları arasinda, ADY1, BING ve SIV1 istasyonları kuzeydoğu yönünde; ARPK ve MALY istasyonları kuzeybatı yönünde; TNCE ve ELAZ istasyonları güneybatı yönüne doğru hareket ettiği belirlenmiştir. DIYB ve ERGN istasyonları, $\theta^{2}$ Ölçütü yöntemine göre kuzeydoğu yönüne, IWST yöntemine göre ise güneydoğu yönüne doğru hareket ettiği tespit edilmiştir. DAFZ 'nin üst kısmında yer alan ARPK, BING, ELAZ, MALY ve TNCE istasyonlarının kendi içerisinde aynı yönde (aşağı) hareket ettiği, DAFZ 'nin alt kIsmında yer alan ADY1, DIYB, ERGN ve SIV1 istasyonlarının da kendi içerisinde aynı yönde (yukarı) hareket ettiği belirlenmiştir.

Genel olarak hareketler incelendiğinde ELAZ, MALY, ERGN, SIV1 ve DIYB istasyonlarında tüm periyotlar arası hareket yönlerinin aynı olduğu, geri kalan ADY1, ARPK, BING ve TNCE istasyonlarında ise hareket yönlerinde değişkenlikler gösterdiği gözlemlenmiştir. Düşey yönde ise BING ve SIV1 istasyonları hariç diğer istasyonların hareket yönlerinde değişkenlik gösterdiği tespit edilmiştir. İstasyonların periyotlar arası yatay ve düşey doğrultuda hangi yöne hareket ettikleri Tablo 8'de ayrıca gösterilmiştir. 
Tablo 8. TUSAGA-Aktif istasyonlarının ölçü periyotları arasındaki hareket yönleri

\begin{tabular}{|c|c|c|c|c|c|c|}
\hline \multirow{2}{*}{$\begin{array}{l}\text { Nokta } \\
\text { Adı }\end{array}$} & \multicolumn{2}{|c|}{$\begin{array}{l}03 \text { Ocak } 2019- \\
05 \text { Nisan } 2019\end{array}$} & \multicolumn{2}{|c|}{$\begin{array}{l}03 \text { Ocak 2019- } \\
28 \text { Aralı } 2019\end{array}$} & \multicolumn{2}{|c|}{$\begin{array}{l}03 \text { Ocak } 2019- \\
25 \text { Ocak } 2020\end{array}$} \\
\hline & Yatay & Düşey & Yatay & Düşey & Yatay & Düșey \\
\hline ADY1 & - & - & - & - & Kuzeydoğu & Așağı \\
\hline ARPK & - & - & - & - & Kuzeybatı & Yukarı \\
\hline BING & - & - & Güneydoğu & Yukarı & Kuzeydoğu & Yukarı \\
\hline DIYB & Kuzeydoğu & - & Kuzeydoğu & Yukarı & $\begin{array}{l}\text { Kuzeydoğu } \\
\text { Güneydoğu }\end{array}$ & Așağl \\
\hline ELAZ & - & - & Güneybatı & - & Güneybatı & Yukarı \\
\hline ERGN & - & - & Doğu & Yukarı & $\begin{array}{l}\text { Kuzeydoğu } \\
\text { Güneydoğu }\end{array}$ & Așağı \\
\hline MALY & Kuzeybatı & Yukarı & Kuzeybatı & Așağg & Kuzeybatı & Yukarı \\
\hline SIV1 & Kuzeydoğu & - & Kuzeydoğu & Așağı & Kuzeydoğu & Așağı \\
\hline TNCE & Güneydoğu & Așağ & Güneybatı & Yukarı & Güneybatı & Yukarı \\
\hline
\end{tabular}

Tablo 8'e göre Elazı̆̆ merkezli meydana depremler TUSAGA-Aktif istasyonlarında yatay hareketin genellikle Kuzey-doğu ve Güney-batı uzanımlı olacak şekilde harekete neden olduğunu göstermektedir.

\section{SONUÇ ve ÖNERILER}

DAFZ üzerinde 2019 ve 2020 yıllarında farklı zamanlarda birçok deprem meydana gelmiştir. 1 Ocak 2019-24 Ocak 2020 tarihleri arasında Elazı̆ İli ve çevresinde farklı tarihlerde ve deprem büyüklüğü 4'ün üzerinde olan üç deprem meydana geldiği tespit edilmiş ve bu depremlerin TUSAGA-Aktif istasyonlarında oluşabilecek konumsal etkilerin incelenmesi amaçlanmıştır. Çalışma kapsamında ilk olarak TUSAGA-Aktif internet arayüzünden deprem günlerinden bir gün sonraki GNSS ölçüleri indirilmiştir. Ardından GNSS ölçüleri değerlendirilmiş, istasyon konum bilgileri ve varyans-kovaryans matrisleri elde edilmiştir. Sonrasında her bir güne ait veriler serbest dengeleme yöntemine göre dengelenmiştir. İki farklı statik deformasyon analiz modeli kullanılarak istasyonların hareketlerinin anlamllıkları incelenmiş, hareket büyüklükleri ve yönleri tespit edilmiştir. Lokal olarak oluşturulan GNSS ağında bulunan istasyonların hepsinin hareketli olma ihtimali göz önüne alınarak iki farklı deformasyon modeli kullanılmıștır. İki yöntem birbirleriyle hemen hemen benzer sonuçlar vermiștir. Fakat iki yöntemin arasındaki en önemli fark 03 Ocak 2019 ile 28 Aralık 2019 periyotları arasındaki karşılaștırmasında, $\theta^{2}$ Ölçütü yöntemine göre SIV1 istasyonunda olmuştur. $\mathrm{Bu}$ istasyonda deformasyon $\theta^{2}$ Ölçütü yöntemine göre belirlenemezken, IWST yöntemi bu istasyonda yaklaşı yatay yönde $0.44 \mathrm{~cm}$, düşey yönde ise -1.36 cm'lik hareket belirlemiştir. 03 Ocak 2019 ile 25 Ocak 2020 periyotları arasındaki karşılaştırmasında, $\theta^{2}$ Ölçütü yöntemine göre BING istasyonunda olmuştur. Bu istasyonda deformasyon $\theta^{2}$ Ölçütü yöntemine göre belirlenemezken, IWST yöntemi bu istasyonda yaklaşı yatay yönde $0.83 \mathrm{~cm}$, düşey yönde ise $2.28 \mathrm{~cm}$ 'lik hareket belirlemiștir. 03 Ocak
2019 ile 28 Aralık 2019 periyotları arasındaki karşılaştırmada tüm istasyonlarda yaklaşılk 4-6 mm'lik yatay hareket belirlenmiştir. Aynı istasyonlarda mutlak olarak da yaklaşık $2.90 \mathrm{~cm}$ 'ye kadar hareket tespit edilmiştir. Deprem büyüklügünün TUSAGA-Aktif istasyonları üzerindeki etkisinin açıkça görüldüğü 03 Ocak 2019 ile 25 Ocak 2020 periyotları arasındaki karșlaștırmada en büyük hareket beklendiği gibi ELAZ istasyonunda meydana gelmiștir. Bu istasyon, yatay doğrultuda yaklaşı $5.5 \mathrm{~cm}$, düşey doğrultuda ise mutlak olarak $2.78 \mathrm{~cm}$ hareket etmiştir. Aynı periyotta düșey yönde mutlak olarak ADY1, ARPK, DIYB, ELAZ,SIV1 ve TNCEistasyonlarında 3 cm'ye yakın ve büyük miktarda hareket belirlenmiştir.;

ERGN ve MALY istasyonlarında ise düşey yönde mutlak olarak $1 \mathrm{~cm}$ hareket tespit edilmiştir. $\mathrm{Bu}$ periyot karşılaştırmasında en büyük düş̧ey yönlü hareket ise $-3.70 \mathrm{~cm}$ ile SIV1 istasyonunda meydana gelmiştir. Belirlenen yatay yönlü hareketlerin yönlerinin genellikle kuzeydoğu, güneydoğu ve güneybatı yönlerinde olması, Doğu Anadolu Fay Zonu' nun hareket özelliği ile uyuşmaktadır.

Yakın zamanda bu konuda, Yalvaç (2020) tarafından yapılan çalışmada hemen hemen aynı TUSAGA-Aktif istasyonları kullanılarak, bu istasyonlarda yatay ve düșey doğrultuda hareketler belirlenmiştir. Yalvaç (2020) tarafından yapılan çalışma sonucu belirlenen yatay yönlü hareketlerin bu çalışma sonuçları ile hemen hemen birbirleriyle örtüştüğü görülmektedir. Diğer taraftan, Yalvaç (2020) tarafından belirlenen düşey yönlü hareketlerin $\mathrm{mm}$ seviyesinde olduğu göz önüne alındığında, bu çalışma kapsamında belirlenen $\mathrm{cm}$ seviyesindeki düsşey yöndeki hareketlerin olması beklenen değerlerden büyük olduğu sonucuna varılabilir. Bu durumun da bu çalışmada kullanılan ticari yazılımdan kaynaklandığı düşünülmektedir. Yine de ticari yazılım kullanarak TUSAGA-Aktif verileri yardımıyla yatay yönlü tektonik hareketlerin belirlenebileceği sonucuna varılabilir. 


\section{BILLGILENDİRME/TEŞEKKÜR}

Yazarlar bu çalıșmada kullanılan TUSAGA-Aktif ağına ilișkin GNSS verilerinin sağlanmasında Tapu ve Kadastro Genel Müdürlüğü ile Harita Genel Müdürlüğü' ne, veri olarak kullanılan IGS (International GNSS Service) ürünlerinden dolayı IGS servisine ve makaleyi değerlendiren hakemlere değerli yorum ve önerileri için teşekkür ederler.

\section{KAYNAKÇA}

Aktuğ, B., Özener, H., Doğru, A., Sabuncu, A., Turgut, B., Halıcıoğlu, K., Yılmaz, O. ve Havazlı, E. (2016). Slip Rates and Seismic Potential on the East Anatolian Fault System Using an Improved GPS Velocity Field. Journal of Geodynamics, (94-95), 1-12.

Aladoğan, K., Tiryakioğlu, İ., Yavaşoğlu, H., Alkan, R.M., Alkan, M.N., Köse, Z., İlçi, V., Ozulu, İ.M., Tombuş, F.E. ve Şahin, M. (2017). Kuzey Anadolu Fayı Bolu-Çorum Segmenti Boyunca Yer Kabuğu Hareketlerinin GNSS Yöntemiyle İzlenmesi. Afyon Kocatepe Üniversitesi Fen ve Mühendislik Bilimleri Dergisi, 17, 997-1003.

Altınoğlu, F.F. (2019). Elazığ ili ve çevresinin çizgisel yapılarının gravite verisine sınır analizi teknikleri uygulanarak belirlenmesi. Pamukkale Üniversitesi Mühendislik Bilimleri Dergisi, 25(6), 785-793.

Anadolu, N.C., ve Kalyoncuoğlu, Ü. Y. (2010). Güneydoğu Anadolu Bölgesinin Depremselliği ve Deprem Tehlike Analizi. Süleyman Demirel Üniversitesi Fen Bilimleri Enstitüsü Dergisi, 14(1), 84-94.

Ansari, K., Çorumluoğlu, Ö. ve Sharma, S.K. (2017). Numerical Simulation of Crustal Strain in Turkey from Continuous GNSS Measurements in the Interval 2009-2017. Journal of Geodetic Science, 7(1), 113-129.

Başkan, G. (2018). Karakoçan ve Halepçe Depremlerinin TUSAGA-Aktif İstasyonlarına Etkilerinin Web Tabanl GNSS Servisiyle İncelenmesi. Yüksek Lisans Tezi. Selçuk Üniversitesi Fen Bilimleri Enstitüsü.

Bayramoğlu, B. (2020). Doğu Anadolu Fay Zonu'nun, Palu Segmentinin, ÜçdeğirmenlerKarşıbahçeler (Palu-Elazığ) Arasında, Paleosismolojik ve Morfotektonik Özellikleri. Yüksek Lisans Tezi. Sivas Cumhuriyet Üniversitesi Fen Bilimleri Enstitüsü.

Caspary, W. F. (1987). Concepts of Network and Deformation Analysis. School of Surveying, University of New South Wales, Monograph No. 11, Kensington, NSW, Australia, 183 s.
Chen, Y. Q. (1983). Analysis of Deformation Surveys - A Generalized Method. Technical Report (94), University of New Brunswick, Fredericton, N.B., Canada, 264 s.

Çoban, K.H., ve Sayıl, N. (2018). Investigation of the seismicity of East Anatolian fault zone (EAFZ) according to Poisson and Exponential distribution models. Düzce Üniversitesi Bilim ve Teknoloji Dergisi, 6, 491-500.

Ervural, S., ve Tuşat, E. (2019). GPS Yayın Efemerisi Doğruluğunun İncelenmesi. Geomatik Dergisi, 4(3), 170-178.

Gelişkan, Ș. (2019). Hassas Nokta Konumlama İle Deformasyonların Belirlenmesi. Yüksek Lisans Tezi. Selçuk Üniversitesi Fen Bilimleri Enstitüsü.

Kavak, U. S. (2020). GNSS Ölçüleriyle Fayların İzlenmesi: Karaburun Fayı Örneği. Yüksek Lisans Tezi. Afyon Kocatepe Üniversitesi Fen Bilimleri Enstitüsü.

Kayıkçı, E.T., ve Yalçınkaya, M. (2015). Determination of Horizontal Movements by Static Deformation Models: A Case Study on the Mining Area. Experimental Techniques, 39 (6), $1-12$.

Kayın, S. (2019). Van Gölü Civarının (Doğu Anadolu) Tektonik Gelişiminin Ve Deformasyonunun Paleomanyetik Çalışmalar İle İncelenmesi. Doktora Tezi. İstanbul Teknik Üniversitesi Fen Bilimleri Enstitüsü.

Khalifa, A. (2018). Morphotectonic Analysis Of The East Anatolian Fault Zone (E. Turkey) Using Remote Sensing Techniques. Doktora Tezi. İstanbul Teknik Üniversitesi Fen Bilimleri Enstitüsü.

Köküm, M. (2019). Landsat TM Görüntüleri Üzerinden Doğu Anadolu Fay Sistemi'nin Palu (Elazığ)-Pütürge (Malatya) Arasındaki Bölümünün Çizgisellik Analizi. Gümüşhane Üniversitesi Fen Bilimleri Enstitüsü Dergisi, 9(1), 119-127.

Kutoğlu, H.S., Toker, M. ve Mekik, C. (2016). The 3-D strain patterns in Turkey using geodetic velocity fields from the RTK-CORS (TR) network. Journal of African Earth Sciences, 115, 246-270.

Öztürk, E., ve Şerbetçi, M. (1992). Dengeleme Hesabı Cilt III. Karadeniz Teknik Üniversitesi Basımevi, Mühendislik-Mimarlık Fakültesi Yayını, 558 s.

Setan, H., ve Singh, R. (2001). Deformation Analysis Of a Geodetic Monitoring Network. Geomatica, 55 (3), 333-346. 
Şahin, A. (2019). Kurucaova Havzası (Doğanşehir, Malatya) Yakın Civarının Neotektonik Özelliklerinin Araştırılması. Yüksek Lisans Tezi. Sivas Cumhuriyet Üniversitesi Fen Bilimleri Enstitüsü.

Tan, A., ve Eyidoğan, H. (2019). The Kinematics of the East Anatolian Fault Zone, Eastern Turkey and Seismotectonic Implications. International Journal of Engineering \& Applied Sciences, 11(4), 494-506.

Tanrıverdi, G.G. (2018). Kahramanmaraş Üçlü Ekleminde Yer Kabuğu Hareketlerinin GPS Ölçüleri İle Belirlenmesi. Yüksek Lisans Tezi. Yıldız Teknik Üniversitesi Fen Bilimleri Enstitüsü.

Taşcı, L. (2010). Analysis Of Dam Deformation Measurements With The Robust And NonRobust Methods. Scientific Research And Essays, 5 (14), 1770-1779.

Ünal, S.K. (2019). Deprem Kavramı Algısı Ve Depreme İlişkin Değerlendirmeler; 8 Mart 2010 Okçular-Kovancılar Depremi Örneği. Yüksek Lisans Tezi. Çanakkale Onsekiz Mart Üniversitesi Fen Bilimleri Enstitüsü.

Ürüşan, A.Y. (2014). Relations Between The GNSS, InSAR and The Other Techniques For Prediction of Earthquakes. Arabian Journal of Geosciences , 8, 7631-7642.

Yalvaç, S. Determining the Effects of the 2020 ElazığSivrice/Turkey (Mw 6.7) Earthquake from the Surrounding CORS-TR GNSS Stations. Turkish Journal of Geosciences, 1(1), 15-20.

Yavaşoğlu, H., Alkan, M. N., Ozulu, İ. M., İlçi, V., Tombuş, F. E., Aladoğan, K., Şahin, M., Tiryakioğlu, İ. ve Kıvrak, S. O. (2015). Recent Tectonic Features of the Central Part (BoluCorum) of the North Anatolian Fault. Hittite Journal of Science and Engineering, 2(1), 77-83.

Yalçınkaya, M. (2003). Monitoring Crustal Movements In West Anatolia By Precision Leveling. Journal Of Surveying Engineering, 129, 44-49.

Yıldırım, Ö., Yaprak, S. ve İnal, C. (2014). Determination Of 2011 Van/Turkey Earthquake $(M=7.2)$ Effects From Measurements Of CORSTR Network. Geomatics, Natural Hazards And Risk, 5(2), 132-144. 